\title{
Comparative population genetic study of two oligophagous insects associated with the same hosts
}

\author{
C Kerdelhué ${ }^{1}$, E Magnoux ${ }^{2}$, F Lieutier ${ }^{3}$, A Roques ${ }^{2}$ and J Rousselet ${ }^{2}$ \\ ${ }^{1} I N R A$, Centre de Bordeaux-Pierroton, UMR BIOGECO, Equipe Entomologie et Biodiversité, 69 route d'Arcachon, F-33612 Cestas \\ cedex, France; ${ }^{2} I N R A$, Centre d'Orléans, Unité de Zoologie Forestière, BP 20619 Ardon, F-45166 Olivet cedex, France; ${ }^{3}$ Université \\ d'Orléans, Laboratoire de Biologie des Ligneux et des Grandes Cultures, BP 6759, F-45067 Orléans cedex 2, France
}

\begin{abstract}
A parallel study of the genetic structure of two oligophagous species associated with the same hosts was conducted to determine the main factors shaping the distribution of genetic diversity. The bark beetle Tomicus piniperda and the pine processionary moth (PPM) Thaumetopoea pityocampa are both associated with the genus Pinus and belong to different guilds (xylophagous vs defoliating species). The PPM is an ectophagous species that feeds on the needles of living trees, whereas $T$. piniperda is endophagous and bores galleries in the inner bark of weakened trees. Both species were sampled in the main regions of France, and their genetic structure was assessed after genotyping with five microsatellite markers. Populations of the PPM were
\end{abstract}

significantly structured. A pattern of isolation by distance was found when distances were calculated as bypassing the Massif Central, whereas no such pattern could be found with raw geographic distances. On the contrary, most populations of $T$. piniperda were not differentiated. No effect of host species could be detected in either of the two species. We conclude that the two taxa have contrasting effective dispersal rates per generation, and we hypothesize that this reflects the different selection pressures acting on individual fitness via different strategies of host use.

Heredity (2006) 97, 38-45. doi:10.1038/sj.hdy.6800836; published online 10 May 2006

Keywords: host use; microsatellites; dispersal; Pinus; Tomicus piniperda; Thaumetopoea pityocampa

\section{Introduction}

Knowledge of the genetic structure of populations is important for the understanding of their ecology and evolution. Extensive gene flow will constrain evolution by preventing local genetic differentiation, whereas reduced dispersal is expected to lead to spatial genetic subdivisions (Slatkin, 1987). Various environmental factors can promote the relative isolation of populations, such as geographic distances, physical barriers to gene flow, habitat (or host-plant) suitability and/or fragmentation (Peterson and Denno, 1998a). Some intrinsic life history or ecological traits (dispersal capacities, occurrence of dispersing life stages, lifespan, adaptability to new environments, and so on) can also be of major importance to shape the distribution of intra-specific diversity (Peterson and Denno, 1998b). Many phytophagous insects are geographically structured, but local adaptation and host-plant fidelity were proved to play a major role in genetic isolation between populations in many cases (Dres and Mallet, 2002). A way to unravel the relative effects of intrinsic and extrinsic factors on the spatial structure of species is to develop a parallel study

Correspondence: C Kerdelhué, INRA, Centre de Bordeaux-Pierroton, UMR BIOGECO, Equipe Entomologie et Biodiversité, 69 route d'Arcachon, F-33612 Cestas cedex, France.

E-mail: Carole.Kerdelhue@pierroton.inra.fr

Received 13 June 2005; accepted 10 April 2006; published online 10 May 2006 of multiple taxa associated with the same host(s) but showing contrasting patterns of host use. Yet, comparative genetic studies are still quite rare, and mostly involve closely related species (Brouat et al, 2003, 2004), or hosts and parasites or mutualists (Jobet et al, 2000; Anderson et al, 2004). We report on a comparative study of two insect species associated with the same hosts (xylophagous vs defoliator), each sampled following the same scheme and analysed with similar neutral markers, to assess the effects of both geographic isolation and host-plant availability on gene flow. By using neutral markers and comparing two species in forests where both commonly occur with quite high population sizes, we expect that most of the observed genetic structure will be due to gene flow and dispersal capacities, as selection and drift will have only limited effects. As far as we know, this paper represents the first attempt to compare levels of genetic structure between two species of insects that share the same host plants. It will provide promising data about the effect of contrasting dispersal characteristics on observed genetic structure, and should stimulate further multi-species parallel genetic studies once specific molecular markers become available.

The xylophagous Tomicus piniperda (L.) (Coleoptera: Scolytidae) and the defoliating pine processionary moth (PPM) Thaumetopoea pityocampa (Denis \& Schiffermüller) (Lepidoptera: Notodontidae: Thaumetopoeinae) both occur in Europe, where they are associated with the genus Pinus. One major constraint acting on the spatial distribution and genetic structure of oligophagous 
insects is host fragmentation and availability. Virtually, any living tree can host PPM nests. Pines are distributed in most regions of France, either as large stands or along the main roads, and individual trees appear to act as connecting hosts between the main forest patches. A strong effect of gene flow could thus be expected for the PPM populations if the inherent dispersal capacities of the moth were not a limiting factor. Yet, the short-lived females are supposed to have limited flight capabilities, dispersing over 3-4 km at most (Démolin, 1969a). We thus expect the PPM to show a high population genetic structure and low levels of gene flow. Conversely, the bark beetle $T$. piniperda mostly develops on weakened or freshly dead pines, which are scarce and widely dispersed in the landscape. If host distribution were the major factors influencing the beetle's genetic structure, one would expect its populations to be highly structured in space. On the other hand, T. piniperda is supposed to have good dispersal capacities and adults disperse twice per generation (once for maturation feeding and once for oviposition). Moreover, owing to the relative rarity of suitable hosts, a proportion of the individuals are expected to necessarily disperse in search of new suitable environments (Lieutier, 2002). Such recurrent long-distance migration would result in low levels of genetic structure.

Until recently, microsatellites were rarely used in studies of Lepidoptera because of paucity of these markers in their genomes (Zhang, 2004). For similar reasons, no such markers had previously been developed in bark beetles (Kerdelhué, personal observations; Stauffer, personal communication). Five microsatellite markers have now been developed for both $T$. piniperda (Kerdelhué et al, 2003) and T. pityocampa (Rousselet et al, 2004), offering a unique opportunity to conduct a parallel study on two oligophagous species with contrasting host-use strategies. We sampled the two species in seven localities corresponding to the main regions of France, and genotyped ca. 30 individuals per population for the five specific microsatellite loci. The main goal of the study was to assess the role of geographic distances, of physical barriers to dispersal and of host tree availability on the spatial subdivision of these two species with different ecological strategies. We also tested whether the host-plant species affected the genetic structure of the associated insects.

\section{Materials and methods}

\section{Insect biological cycles}

The bark beetle T. piniperda and the PPM T. pityocampa typically have one generation per year in France. In both species, mating takes place on the host, and larvae feed on pine until the pupal stage.

T. piniperda has a Palaearctic distribution. At the end of winter, females bore galleries under the bark of a weakened or dead pine tree, where they lay eggs. Complete larval development takes place on the same host, and the larvae feed from the inner bark. Young adults emerge in late spring, and disperse to the shoots of surrounding living trees to complete the obligatory maturation feeding during summer. After overwintering, either in the shoots or under the bark at the base of the trunks, mature adults fly to a suitable host for reproduction the following year (Chararas, 1962). This species thus has two dispersal phases per generation.

The PPM is a native of the Mediterranean Basin, and shows a recent expansion to upper elevations and latitudes, most probably owing to climate warming (Battisti et al, 2005). Adult moths of T. pityocampa emerge and lay eggs on pine leaves in summer. Larvae feed on pine needles during fall and winter, and show gregarious behaviour such that colonies from different egg patches usually cluster together in large silk nests built on the top of the tree. Throughout larval development, the caterpillars feed on needles at night on the host where they hatched, but can walk to surrounding pines if the primary host is completely defoliated. They pupate in the soil in late winter or early spring, and newly emerged adults will disperse to reproduce either the following summer or 1-3 years later if prolonged diapause occurs (Démolin, 1969b).

\section{Insect sampling}

$T$. piniperda and $T$. pityocampa were both sampled in Orléanais, Landes, Pyrénées, the Massif Central and Alps, thus covering the main regions of France. T. piniperda was also collected from Alsace, where the moth does not occur. Both insects were thus sampled from three native pine species, namely Pinus sylvestris, $P$. pinaster and $P$. uncinata. Sampling data are given in Table 1, and the localities are shown in Figure 1. Attacking adults of $T$. piniperda were collected between February and April 2000 on trap trees, cut in November and December 1999. For each locality, 30 individuals were sampled while boring the maternal galleries. Collecting attacking Tomicus rather than emerging adults prevents the sampling of siblings. The PPMs were sampled during L2-L3 larval stages in autumn 2002. Thirty trees were chosen in each pine stand, and one caterpillar was collected on each tree. All larvae sampled in one locality thus belong to different broods as the PPM females are known to lay all their eggs on the same tree

Table 1 Sampling sites for T. pityocampa (PPM) and T. piniperda in France

\begin{tabular}{|c|c|c|c|c|c|}
\hline Locality & Coordinates, PPM & Coordinates, Tomicus & Host species & \# PPM & \# Tomicus \\
\hline Orléanais & $47^{\circ} 49^{\prime} \mathrm{N}-2^{\circ} 29^{\prime} \mathrm{W}$ & $47^{\circ} 55^{\prime} \mathrm{N}-2^{\circ} 18^{\prime} \mathrm{W}$ & P. sylvestris & 30 & 30 \\
\hline Landes & $44^{\circ} 44^{\prime} \mathrm{N}-0^{\circ} 46^{\prime} \mathrm{W}$ & $45^{\circ} 11^{\prime} \mathrm{N}-1^{\circ} 09^{\prime} \mathrm{W}$ & P. pinaster & 30 & 30 \\
\hline Pyrénées-S & $42^{\circ} 23^{\prime} \mathrm{N}-2^{\circ} 00^{\prime} \mathrm{W}$ & $42^{\circ} 48^{\prime} \mathrm{N}-2^{\circ} 16^{\prime} \mathrm{W}$ & P. sylvestris & 30 & 30 \\
\hline Pyrénées-U & $42^{\circ} 24^{\prime} \mathrm{N}-1^{\circ} 59^{\prime} \mathrm{W}$ & $42^{\circ} 29^{\prime} \mathrm{N}-2^{\circ} 08^{\prime} \mathrm{W}$ & P. uncinata & 33 & 30 \\
\hline Massif Central & $45^{\circ} 18^{\prime} \mathrm{N}-3^{\circ} 29^{\prime} \mathrm{W}$ & $45^{\circ} 20^{\prime} \mathrm{N}-3^{\circ} 26^{\prime} \mathrm{W}$ & P. sylvestris & 31 & 30 \\
\hline Alps & $44^{\circ} 04^{\prime} \mathrm{N}-6^{\circ} 34^{\prime} \mathrm{W}$ & $43^{\circ} 58^{\prime} \mathrm{N}-6^{\circ} 30^{\prime} \mathrm{W}$ & P. sylvestris & 29 & 30 \\
\hline Alsace & - & $47^{\circ} 52^{\prime} \mathrm{N}-7^{\circ} 27^{\prime} \mathrm{W}$ & P. sylvestris & - & 30 \\
\hline
\end{tabular}

PPM, pine processionary moth. 


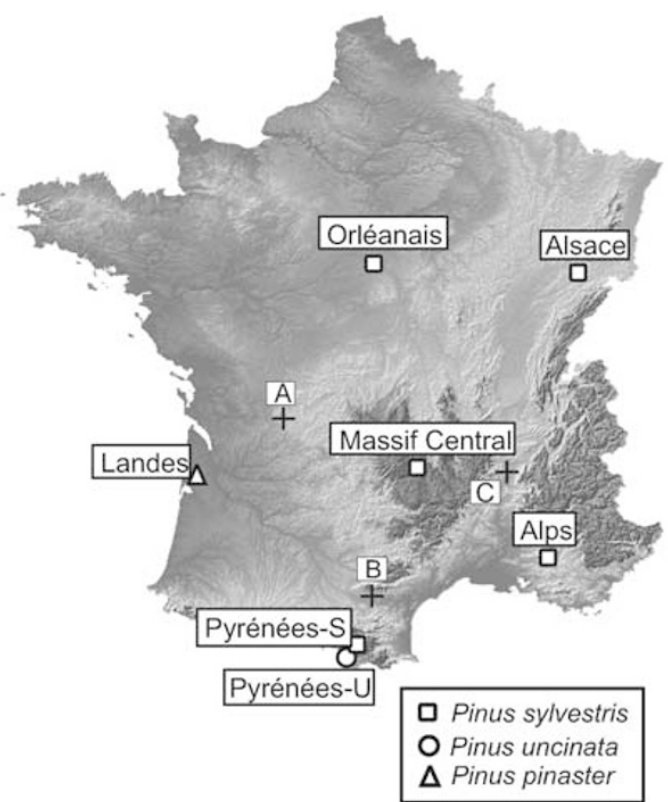

Figure 1 Map of the sampling localities. Both $T$. piniperda and $T$. pityocampa were sampled for each locality, except in Alsace, where the moth does not occur. Points A, B and C were used to recalculate geographic distances as if the mountainous region of Massif Central was a perfect barrier to gene flow. Intercarto 2005.

(Huchon and Démolin, 1970). All insects were killed and stored in absolute ethanol until DNA extraction.

\section{DNA protocols}

DNA was extracted from the whole body of PPM larvae and from the head and thorax of adult Tomicus, following the procedure of either the DNeasy Tissue Kit (Qiagen) or the GenElute Mammalian Genomic DNA Miniprep Kit (Sigma). In all cases, purified DNA was eluted in $200 \mu \mathrm{l}$ of pure water.

We genotyped 184 T. pityocampa and 210 T. piniperda for five microsatellite loci each (namely MS-Thpit1, MSThpit2, MS-Thpit3, MS-Thpit4 and MS-Thpit5 for the PPM and CT2-8F, CT2-5F, CT1-4F, CT2-5H and CT1-8B for T. piniperda). Microsatellite primers and amplification conditions for each species are described elsewhere (Kerdelhué et al, 2003; Rousselet et al, 2004). Fluorescent PCR products were run and detected on an ABI 3100 automatic sequencer (Applied Biosystems) and product size was determined using GeneScan software (Applied Biosystems).

\section{Data analyses}

Observed and unbiased expected heterozygosities (Nei, 1978) as well as allelic richness and allelic frequencies were calculated using GENETIX version 4.04 (Belkhir et al, 1996-2004). For each locus and population, deviations from Hardy-Weinberg equilibrium and linkage disequilibria were tested with ARLEQUIN version 2.001 (Schneider et al, 2000), with 10000 permutations.

Population structure was analysed using $F_{\text {st }}$ (Weir and Cockerham, 1984) and $R_{\mathrm{st}}$ (Michalakis and Excoffier, 1996; Rousset, 1996) as recommended by Balloux and Lugon-Moulin (2002). Global fixation indices were calculated using GENEPOP version 3.3 (Raymond and Rousset, 1995), whereas the population pairwise $\theta_{\mathrm{ST}}$ and pairwise $\rho_{\mathrm{ST}}$ were calculated using ARLEQUIN. Their significance was estimated using 3000 permutations. A test of population differentiation was performed using GENEPOP. Neighbour-joining trees of populations (Saitou and Nei, 1987) were constructed using Cavalli-Sforza and Edwards' chord distance. Bootstrap values were computed by resampling loci and are given as a percentage of 2000 replicates. Trees were reconstructed using POPUlATIONS 1.2.28 (O Langella, http:// www.pge.cnrs-gif.fr/bioinfo/populations/index.php). A Mantel test for isolation by distance was performed using GENETIX to test the correlations between $\left(\theta_{\mathrm{ST}} /\right.$ $\left.\left(1-\theta_{\mathrm{ST}}\right)\right)$ and the geographical distance among populations (Rousset, 1997). Significance was assessed with 500 permutations. Even moderate altitudes such as the Massif Central and the low relief that links it to the Ardennes in the north of France could play a role in isolating the PPM populations, as they are cold-sensitive. We tested the two extreme scenarios: that is, one in which no physical barrier limits gene flow and one in which the moderate altitudes are a perfect barrier to migration. We compared the matrix of genetic distances both to a matrix of geographic distances measured as the crow flies and to a matrix of recalculated distances assuming that crossing these mountains was impossible. In the second case, the insects were thus assumed to bypass the mountain ranges to the south, and distances were recalculated as if individuals had to go through points A, B and/or C (Figure 1) instead of flying above the relief. For instance, distance between Landes (in southwestern France) and the Alps was recalculated as the distance between Landes and point $\mathrm{B}+$ the distance between point $\mathrm{B}$ and the Alps.

\section{Results}

\section{Allelic richness, heterozygosities and tests of Hardy-Weinberg equilibria}

For the PPM, the number of alleles per locus ranged from eight for MS-Thpit5 to 19 for MS-Thpit2, MS-Thpit3 and MS-Thpit4. For each population, the mean number of alleles per locus ranged from 6.6 in Orléanais to 11.6 in Pyrénées-U. Observed heterozygosities within populations were lowest (0.63) in Orléanais, Massif Central and Alps, and highest in Pyrénées-U (0.75). Among all pairwise tests of linkage disequilibrium, six were found significant but involved different pairs of loci. Only five tests showed a significant deviation from Hardy-Weinberg equilibrium (MS-Thpit1 in Pyrénées-U, MS-Thpit4 in Pyrénées-S and Massif Central, MS-Thpit2 in Massif Central and Landes). All populations could thus be considered at equilibrium, and no locus showed a biased allelic distribution.

The number of alleles per locus for T. piniperda ranged from four for $\mathrm{CT} 2-5 \mathrm{H}$ to 51 for CT2-5F. For each population, the mean number of alleles per locus ranged from 9.6 in Massif Central and Alps to 10.8 in PyrénéesU. Observed heterozygosities within populations were between 0.63 in Orléanais and 0.70 in Alps. Among all pairwise tests of linkage disequilibrium, only three were found significant, involving different pairs of loci. Eight tests showed a significant deviation from Hardy-Wein- 
berg equilibrium, four of which involved locus CT1-4F. However, no population had more than two disequilibria. All calculations were repeated excluding locus CT1-4F because of the possible disequilibrium.

\section{Population genetic structure}

The PPM showed a significant pattern of population differentiation (exact test of population differentiation, $P<0.001$ for each locus and for the whole data set). Global $F_{\text {st }}$ was 0.107 and global $R_{\text {st }}$ reached 0.197. All pairwise $F_{\mathrm{st}}$ and $R_{\mathrm{st}}$ values were significant, except for the comparison between the neighbouring populations from the Pyrénées sampled on $P$. sylvestris and $P$. uncinata (see Table 2 ). $R_{\mathrm{st}}$ values were mostly greater than $F_{\mathrm{st}}$, but both indices showed the same pattern of population differentiation. Three pairs of populations were weakly structured (namely Massif Central-Alps, Landes-Pyrénées-S and Landes-Pyrénées-U; $F_{\mathrm{st}}<0.06$ ). All pairs involving Orléanais (except for the comparison with Landes), Landes-Alps and Landes-Massif Central had quite high fixation indices $\left(0.14<F_{\text {st }}<0.22\right)$. The pattern of isolation-by-distance was not significant when considering distances as the crow flies $(P=0.118)$, but appeared highly significant when considering geographic distances bypassing the Massif Central $(r=0.980, P<0.001$; see Figure 2$)$.

Populations of $T$. piniperda were significantly differentiated $(P<0.01$ : exact test for each locus and for the whole data set). Both $F_{\text {st }}$ and $R_{\text {st }}$ values were one order of magnitude lower than for the populations of the PPM, as global $F_{\text {st }}$ and $R_{\text {st }}$ were 0.016 and 0.009 , respectively. Most pairwise comparisons of $R_{\text {st }}$ were not significant (see Table 3). $F_{\text {st }}$ estimates reached a maximum of 0.045 . Except for the population pair Orléanais-Pyrénées-U, all pairwise $F_{\text {st }}$ involving Orléanais and Alsace were significant. Pairwise $F_{\text {st }}$ between the Alps and Pyrénées-S, and the Alps and Pyrénées-U were also significant. All other pairwise comparisons were nonsignificant (see Table 3 ). When the same $F_{\mathrm{st}}$ and $R_{\mathrm{st}}$ estimators were calculated without locus CT1-4F (excluded from the analyses because of its inherent disequilibria, see above), very similar results were found, except that some population pairs were no longer significantly structured (namely Orléanais-Pyrénées-S and Orléanais-Massif Central). We found a slight but significant effect of isolation by distance when considering distances as the crow flies $(r=0.453 ; P=0.036)$. The pattern was no longer significant when considering distances bypassing Massif Central ( $r=0.552 ; P=0.138$; see Figure 2). The same results were found when locus CT1-4F was omitted.
For both species, the phylogenetic trees of populations are shown in Figure 3. For the PPM, the populations of Massif Central and Alps were grouped together and separated from the other populations. Another clade contained the Pyrenean populations (Pyrénées-S and Pyrénées-U), whereas northern and western populations (namely Orléanais and Landes) were clustered together. The tree obtained with the populations of T. piniperda had a star shape, showing poor resolution of clades, except in
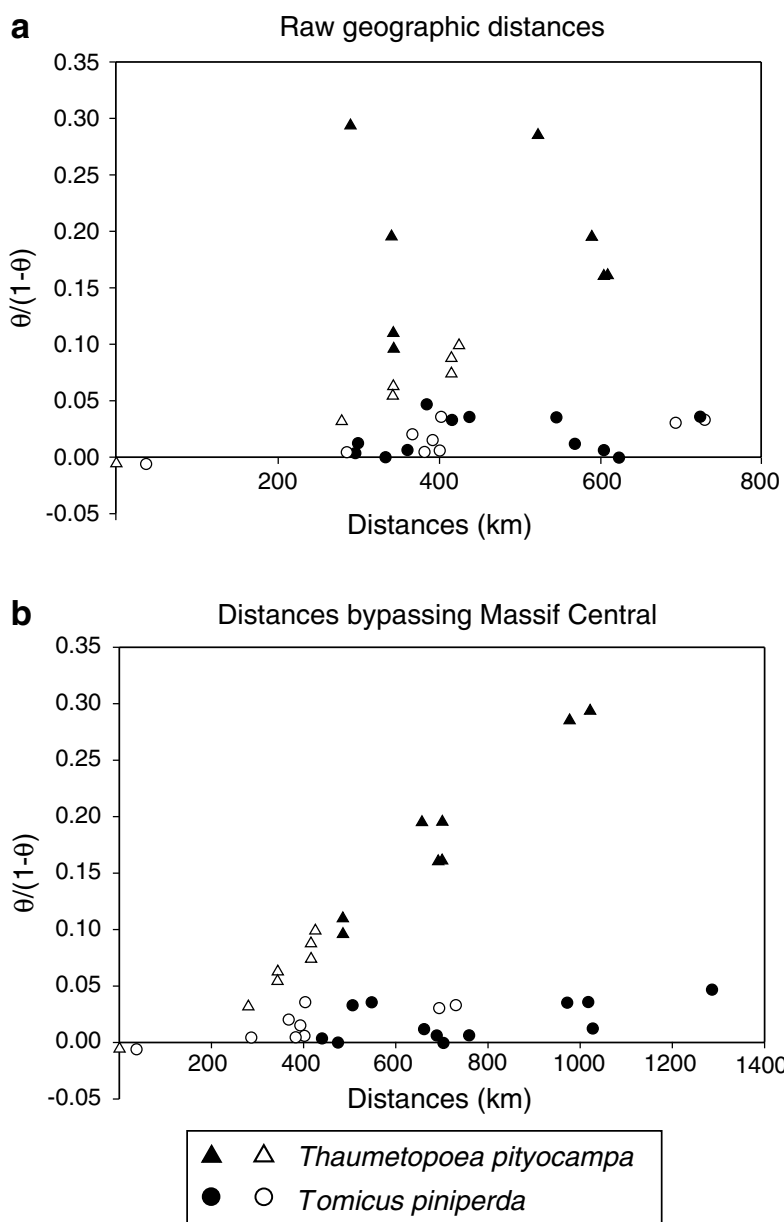

Figure 2 Plots of genetic differentiation (estimated as $\theta_{\mathrm{ST}} /\left(1-\theta_{\mathrm{ST}}\right)$ ) against the geographic distance (in $\mathrm{km}$ ) for all pairs of sampled populations in both $T$. piniperda (circles) and $T$. pityocampa (triangles). (a) Bird geographic distances. (b) Geographic distances bypassing Massif Central. Open symbols correspond to pairs of populations for which the bird distance is the same as the distance bypassing Massif Central.

Table $2 F_{\mathrm{st}}$ (below diagonal) and $R_{\mathrm{st}}$ (above diagonal) pairwise estimates obtained for the pine processionary moth T. pityocampa

\begin{tabular}{|c|c|c|c|c|c|c|}
\hline & Orléanais & Pyrénées-S & Pyrénées-U & Massif Central & Landes & Alps \\
\hline Orléanais & & $0.281^{* *}$ & $0.275^{* *}$ & $0.439 * *$ & $0.207^{* *}$ & $0.346^{* *}$ \\
\hline Pyrénées-S & $0.139 * *$ & & $-0.005 \mathrm{NS}$ & $0.143^{* *}$ & $0.066^{* *}$ & $0.096^{* *}$ \\
\hline Pyrénées-U & $0.138^{* *}$ & $-0.005 \mathrm{NS}$ & & $0.213^{* *}$ & $0.041^{*}$ & $0.159^{* *}$ \\
\hline Massif Central & $0.227^{* *}$ & $0.100^{* *}$ & $0.087^{* *}$ & & $0.329^{* *}$ & $0.029^{*}$ \\
\hline Landes & $0.090^{* *}$ & $0.052^{* *}$ & $0.059^{* *}$ & $0.163^{* *}$ & & $0.248^{* *}$ \\
\hline Alps & $0.222^{* *}$ & $0.082^{* *}$ & $0.069^{* *}$ & $0.031^{* *}$ & $0.163^{* *}$ & \\
\hline
\end{tabular}

NS, nonsignificant; ${ }^{*} P<0.05 ;{ }^{* *} P<0.01$. 
Table $3 F_{\mathrm{st}}$ (below diagonal) and $R_{\mathrm{st}}$ (above diagonal) pairwise estimates obtained for the bark beetle T. piniperda

\begin{tabular}{|c|c|c|c|c|c|c|c|}
\hline & Orléanais & Pyrénées-S & Pyrénées-U & Massif central & Landes & Alps & Alsace \\
\hline Orléanais & & $0.020 \mathrm{NS}$ & $-0.014 \mathrm{NS}$ & $0.062^{*}$ & $0.025 \mathrm{NS}$ & $0.053^{*}$ & -0.005 NS \\
\hline Pyrénées-S & $0.012^{*}$ & & $0.002 \mathrm{NS}$ & $-0.007 \mathrm{NS}$ & $-0.015 \mathrm{NS}$ & -0.011 NS & -0.002 NS \\
\hline Pyrénées-U & $0.006 \mathrm{NS}$ & $-0.006 \mathrm{NS}$ & & $0.035 \mathrm{NS}$ & $0.007 \mathrm{NS}$ & $0.027 \mathrm{NS}$ & $-0.009 \mathrm{NS}$ \\
\hline Massif central & $0.012^{*}$ & $0.004 \mathrm{NS}$ & $-0.0001 \mathrm{NS}$ & & $-0.010 \mathrm{NS}$ & $-0.009 \mathrm{NS}$ & $0.027 \mathrm{NS}$ \\
\hline Landes & $0.034^{* *}$ & $0.005 \mathrm{NS}$ & $0.006 \mathrm{NS}$ & $0.006 \mathrm{NS}$ & & $-0.012 \mathrm{NS}$ & $0.001 \mathrm{NS}$ \\
\hline Alps & $0.034^{* *}$ & $0.020^{* *}$ & $0.015^{*}$ & 0.004 NS & $-0.0004 \mathrm{NS}$ & & $0.020 \mathrm{NS}$ \\
\hline Alsace & $0.045^{* *}$ & $0.030^{* *}$ & $0.032^{* *}$ & $0.032^{* *}$ & $0.035^{* *}$ & $0.034^{* *}$ & \\
\hline
\end{tabular}

NS, nonsignificant; ${ }^{*} P<0.05 ;{ }^{* *} P<0.01$.

a

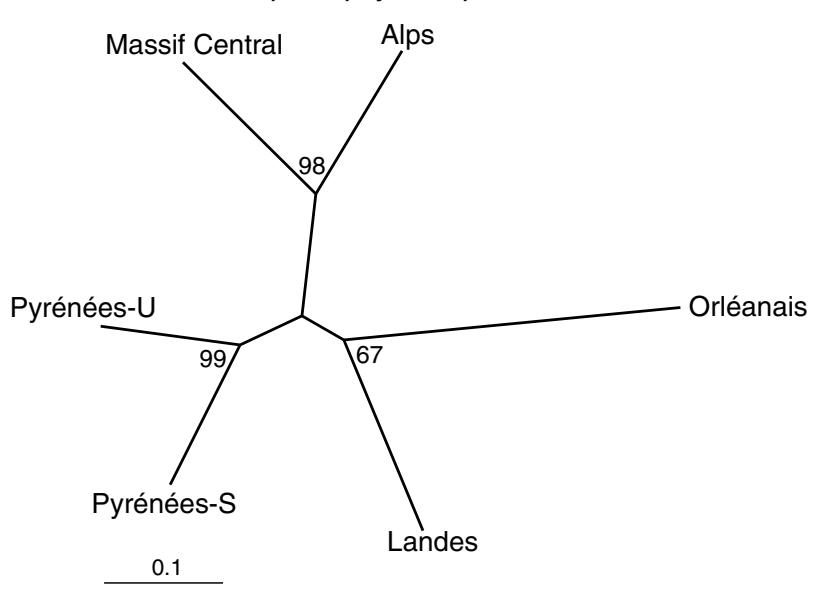

b

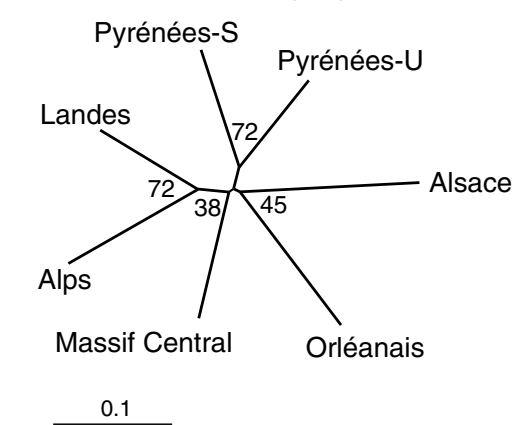

Figure 3 Neighbour-joining trees of populations for both insect species. (a) T. pityocampa. (b) T. piniperda.

the case of Landes-Alps. The two Pyrenean populations, sampled on different hosts, clustered together.

\section{Discussion}

This parallel study on two insects associated with the same hosts and analysed with similar neutral molecular markers yielded contrasting results, even though intrapopulation parameters were very similar in both species (allelic richness and heterozygosities). Because of a lack of species replication (Garland and Adolph, 1994), one should be cautious in concluding which factor(s) most influenced the spatial genetic structure. However, it is plausible that selection did not significantly affect our results, as we inferred population structure from independent markers for which no evidence of nonneutral evolution was found. Gene flow and drift are thus the factors most likely to have shaped genetic differentiation between populations.

Our sampling design does not permit us to rule out a role for genetic drift on the observed genetic structure. Yet, both species are known to be common in the locations we sampled for the present study, and even though no direct estimates of population levels are available, we can hypothesize that the genetic structure was mainly explained by migration and gene flow. Comparative studies of genetic structure are still rare in the literature. Their development is limited by the difficulties of parallel sampling and by the lack of usable microsatellite markers for many species, in particular in lepidopteran and scolytid insects. Future research should seek to develop multi-species comparative studies with higher sampling densities to better understand the role of dispersal.

\section{Genetic structure and gene flow in T. piniperda}

\section{and $T$. pityocampa}

The bark beetle $T$. piniperda showed both low levels of population differentiation and only few significant values of pairwise $F_{\text {st }}$. Its populations were very weakly differentiated, with a limited effect of isolation by distance. Populations distant by up to $600 \mathrm{~km}$ were not significantly structured, with $F_{\text {st }}$ values as low as 0.006 (see Table 3). Migration between populations is thus probably common in this species. Its inherent dispersal abilities are poorly known, but our study and other evidence suggest that a fraction of the individuals is probably involved in long-range movements. Dispersal occurs twice during the beetle development (for maturation feeding and for reproduction). Moreover, females usually do not lay all their eggs in the same gallery, but rather re-emerge to search for other suitable oviposition sites (Sauvard, 1993). Flying ability has certainly been favoured by natural selection owing to the relative rarity of suitable hosts. In addition, most pines are able to counteract single beetle attacks by induced resistance reactions (Bois and Lieutier, 2000). In most bark beetle species, establishment on conifers is thought to be possible only once a critical threshold of attack density is reached, above which the defence system of the tree is exhausted (Raffa and Berryman, 1983). T. piniperda mostly attacks weakened trees, as the threshold is supposed to be very high for this species on living trees (Lieutier, 2002). The major ecological constraint acting on the fitness of T. piniperda is thus most probably hosts' 
resistance capacities. Good foraging abilities have been favoured to permit host localization and aggregation of adults during trunk attack. Comparable high effective dispersal and subsequent lack of genetic differentiation over a large scale has recently been shown for the bark beetle Ips typographus (Sallé et al, 2006) and should probably be expected in most scolytid species that have evolved under similar constraints of host use. In addition to the beetles' natural dispersal capacities, one can hypothesize that transportation of cut trees owing to human activities such as wood trade could play a role in homogenizing Tomicus population genetic structure.

Conversely, the PPM appeared to be highly spatially subdivided. This oligophagous insect is significantly structured even between locations like Orléanais and Landes, where no relief could act as an isolating barrier. Strong population structure had already been found in Italy, using both mitochondrial and AFLP markers (Salvato et al, 2002). In this particular case, however, differentiation of populations could be explained both by the fact that some of the sampling areas were located in newly colonized zones, and by the limited connections between Alpine valleys. Our results suggest that PPM populations are genetically structured even in flat areas without major host gaps. PPM larvae develop during winter and group together in a single nest to survive lower temperatures. Moth fitness is thus linked to winter survival of larvae rather than to host suitability. Female capacity to lay enough eggs for colony development is critical, whereas localization of a favourable host is not (at least in places where pines are abundant). In this context, natural selection has probably favoured females with bigger egg masses rather than high dispersal abilities. It is noticeable that some other forest lepidopteran defoliators such as the European gypsy moth Lymantria dispar (L.) and the winter moth Operophtera brumata (L.) exhibit similar patterns of low female dispersal combined with large egg masses (Van Dongen et al, 1996; Liebhold et al, 2000). Likewise, the gregarious sawflies Diprion pini L. and Neodiprion sertifer (Geoffroy) probably evolved under comparable ecological constraints and could be expected to exhibit the same patterns of population differentiation owing to a reduced mobility associated with a higher reproductive allocation (Codella and Raffa, 1993; Herz and Heitland, 2002).

PPM males can be attracted to pheromone traps located at ca. $20 \mathrm{~km}$ away from the nearest infested pine forest (A Roques and J Rousselet, personal observation). Our results show that long-range dispersal of the males is not sufficient to homogenize the genetic structure of the moth over France. This suggests that such movements remain occasional at least in core populations. Yet, the geographical range of the PPM is rapidly increasing polewards with global warming (Battisti et al, 2005), which suggests that the species is capable of efficient dispersal to new suitable environments in the expansion zones. The dispersal capacities of both sexes could nonetheless play a role in the founding and success of expanding populations, which should be tested experimentally in the future. A recent study comparing the genetic diversity of males caught in pheromone traps to larvae hatched in the same location showed substantial homogeneity between adults and caterpillars in core populations but not in expanding zones (Salvato et al, 2005), which corroborates our hypothesis.
Role of host-plant species

No clear pattern of host-mediated differentiation appeared from our study for either of the two species. In both T. pityocampa and T. piniperda, the two neighbouring populations from the Pyrénées, respectively sampled from $P$. sylvestris and $P$. uncinata, were genetically indistinguishable. Similarly, individuals sampled on $P$. pinaster in Landes were not more differentiated from other Western populations (Orléanais, Pyrénées-S and Pyrénées-U) than expected under isolation by distance alone. No host-specific alleles could be detected. This pattern suggests that host specialization is not a strong factor influencing the evolution of the species, at least within this restricted group of host tree species. Yet, a previous study of host-plant specialization in T. piniperda using mitochondrial markers showed a weak but significant effect of host species as a barrier to gene flow (Kerdelhué et al, 2002). The different results obtained with nuclear and mitochondrial markers could be due to sex-biased dispersal. A similar hypothesis was proposed for the bark beetle Ips typographus (Sallé et al, 2006). A specific sampling design including several populations for each host species should now be used to address the question of the role of host plant in the genetic differentiation of the associated insects. The eventual isolation of the Mediterranean populations of the PPM as well as those developing on non-pine hosts such as Cedrus spp or Douglas fir remains to be addressed.

\section{Roles of geographic barriers}

The tests of isolation by distance show that the Massif Central plays a key role in isolating populations of the PPM only. All locations separated by the Massif Central have much higher $F_{\text {st }}$ and $R_{\text {st }}$ values. This moderate relief thus appears to be sufficient to strongly limit gene flow between moth populations, but does not act as a barrier between populations of T. piniperda. This difference can be explained as $T$. piniperda is known from high elevations, whereas the PPM is more cold-sensitive. The correlation between geographical distances recalculated as if the Massif Central was a perfect barrier and fixation indices is very high in the PPM $(r=0.98)$. Our data suggest that moths virtually never cross this upland range, but rather that the populations can expand on the slopes and in valleys of the Massif Central from surrounding localities. The key role played by Massif Central in isolating populations of the PPM will require a specific study, with systematic sampling of the PPM on each side of the Massif and a higher density of sampled populations for all distance classes. Under such conditions, one might be able to better analyse the dispersal curve of the species and to test different models of dispersal against the observed genetic structure. At a larger spatial scale, we would also expect that the main European and North African mountainous ranges such as the Pyrénées, the Alps and the Atlas efficiently reduced genetic exchange between populations. They would have also played a significant role in the recent past during postglacial recolonization. For the coldtolerant T. piniperda, Ritzerow et al (2004) suggested the existence of refugial areas both in southern Europe and in Russia, and showed that the Pyrénées acted as an impediment to postglacial expansion. No data are yet available for the PPM, but it survived the ice ages only in 
southern refugia. It will now be necessary to develop phylogeographical studies for both species in order to understand how their recent history may have influenced the current distribution of genetic diversity.

\section{Acknowledgements}

We are grateful to J Garcia, F Goussard, P Pineau and P Ménassieu for field sampling of both T. piniperda and T. pityocampa. We thank J-C Martin and $\mathrm{R}$ Mazet for sampling and technical assistance. Messrs T Noblecourt, L Micas and M Liénard kindly permitted us to cut trap trees and to sample insects from forest stands, and guided us in the field. A Robert and C Chaline are greatly acknowledged for their lab work. We also thank two anonymous reviewers as well as C LopezVaamonde, whose comments strongly improved the manuscript. Microsatellite development and genotyping for the PPM was supported by the EU project PROMOTH (QLK5-2001-00852).

\section{References}

Anderson B, Olivieri I, Lourmas M, Stewart BA (2004). Comparative population genetic structures and local adaptation of two mutualists. Evolution 58: 1730-1747.

Balloux F, Lugon-Moulin N (2002). The estimation of population differentiation with microsatellite markers. Mol Ecol 11: 155-165.

Battisti A, Stastny M, Netherer S, Robinet C, Schopf A, Roques A et al (2005). Expansion of geographic range in the pine processionary moth caused by increased winter temperatures. Ecol Appl 15: 2084-2096.

Belkhir K, Borsa P, Chikhi L, Raufaste N, Bonhomme F (1996-2004). GENETIX 4.05, logiciel sous Windows ${ }^{\mathrm{TM}}$ pour la génétique des populations. Laboratoire Génome, Populations, Interactions, CNRS UMR 5000, Université de Montpellier II, Montpellier (France)

Bois E, Lieutier F (2000). Resistance level in Scots pine clones and artificial introductions of Tomicus piniperda (Col Scolytidae) and Leptographium wingfieldii (Deuteromycetes). J Appl Entomol 124: 163-167.

Brouat C, Chevallier H, Meusnier S, Noblecourt T, Rasplus J-Y (2004). Specialization and habitat: spatial and environmental effects on abundance and genetic diversity of forest generalist and specialist Carabus species. Mol Ecol 13: 1815-1826.

Brouat C, Sennedot F, Audiot P, Leblois R, Rasplus J-Y (2003). Fine-scale genetic structure of two carabid species with contrasted levels of habitat specialization. Mol Ecol 12: 1731-1745.

Chararas C (1962). Etude biologique des Scolytides des conifères. XXXVIII. Editions Paul Lechevalier: Paris, France.

Codella Jr SG, Raffa KR (1993). Defense strategies of folivorous sawflies. VII. Gregarious behavior: multiple selection pressures?. In: Wagner M, Raffa KR (eds) Sawflies Life History Adaptation to Woody Plants. Academic Press: San Diego. pp 279-284.

Démolin G (1969a). Comportement des adultes de Thaumetopoea pityocampa Schiff. Dispersion spatiale, importance écologique. Ann Sci Forest 26: 81-102.

Démolin G (1969b). Bioecologia de la procesionaria del pino Thaumetopoea pityocampa Schiff. Incidencia de los factores climaticos. Bol Serv Plagas For 12: 9-24.

Dres M, Mallet J (2002). Host races in plant-feeding insects and their importance in sympatric speciation. Philos Trans Roy Soc London B 357: 471-492.

Garland Jr T, Adolph SC (1994). Why not to do two-species comparative studies: limitations on inferring adaptation. Physiol Zool 67: 797-828.
Herz A, Heitland W (2002). Comparison of the fat allocation patterns in female pine sawflies (Hymenoptera: Diprionidae). Eur J Entomol 99: 117-120.

Huchon H, Démolin G (1970). La bioécologie de la processionnaire du pin. Dispersion potentielle - Dispersion actuelle. Rev For Fr 22: 220-234.

Jobet E, Durand P, Langand J, Müller-Graf CDM, Hugot JP, Bougnoux ME et al (2000). Comparative genetic diversity of parasites and their hosts: population structure of an urban cockroach and its haplo-diploid parasite (oxyuroid nematode). Mol Ecol 9: 481-486.

Kerdelhué C, Mondor-Genson G, Rasplus J-Y, Robert A, Lieutier F (2003). Characterization of 5 microsatellite loci in the pine shoot beetle Tomicus piniperda (Coleoptera: Scolytidae). Mol Ecol Notes 3: 100-101.

Kerdelhué C, Roux-Morabito G, Forichon J, Chambon J-M, Robert A, Lieutier F (2002). Population genetic structure of Tomicus piniperda L. Coleoptera: Scolytidae) and validation of T. destruens (Woll.). Mol Ecol 11: 483-494.

Liebhold A, Elkinton J, Williams D, Muzika RM (2000). What causes outbreaks of the gypsy moth in North America? Popul Ecol 42: 257-266.

Lieutier F (2002). Mechanisms of resistance in conifers and bark beetle attack strategies. In: Wagner MR, Clancy KM, Lieutier F, Paine TD (eds) Mechanisms and Deployment of Resistance in Trees to Insects. Kluwer Academic Publishers: Dordrecht. pp 31-77.

Michalakis Y, Excoffier L (1996). A generic estimation of population subdivision using distances between alleles with special reference for microsatellite loci. Genetics 142: 1061-1064.

Nei M (1978). Estimation of average heterozygosity and genetic distance from a small number of individuals. Genetics 89: 583-590.

Peterson MA, Denno RF (1998a). The influence of dispersal and diet breadth on patterns of genetic isolation by distance in phytophagous insects. Am Nat 152: 428-446.

Peterson MA, Denno RF (1998b). Life history strategies and the genetic structure of phytophagous insect populations. In: Mopper S, Strauss SH (eds) Genetic Structure and Local Adaptation in Natural Insect Populations: Effect of Ecology, Life History, and Behavior. Chapman \& Hall: New-York. pp 263-322.

Raffa KF, Berryman AA (1983). The role of host plant resistance in the colonization behavior and ecology of bark beetles (Coleoptera: Scolytidae). Ecol Monogr 53: 27-49.

Raymond M, Rousset F (1995). GENEPOP (version 1.2): a population genetics software for exact tests and eucumenicism. J Hered 86: 248-249.

Ritzerow S, Konrad H, Stauffer C (2004). Phylogeography of the Eurasian pine shoot beetle Tomicus piniperda L. (Coleoptera, Scolytidae). Eur J Entomol 101: 13-19.

Rousselet J, Magnoux E, Kerdelhué C (2004). Characterization of five microsatellite loci in the pine processionary moth Thaumetopoea pityocampa (Lepidoptera Notodontidae Thaumetopoeinae). Mol Ecol Notes 4: 213-214.

Rousset F (1996). Equilibrium values of measures of population subdivision for stepwise mutation processes. Genetics 142: 1357-1362.

Rousset F (1997). Genetic differentiation and estimation of gene flow from F-statistics under isolation by distance. Genetics 145: 1219-1228.

Saitou N, Nei M (1987). The neighbor-joining method: a new method for reconstructing phylogenetic trees. Mol Biol Evol 4: 406-425.

Sallé A, Arthoffer W, Lieutier F, Stauffer C, Kerdelhué C (2006). Phylogeography of a species-specific insect: genetic structure of Ips typographus in Europe does not reflect the past fragmentation of its host. Biol J Linn Soc (in press).

Salvato P, Battisti A, Concato S, Masutti L, Patarnello T, Zane L (2002). Genetic differentiation in the winter pine processionary moth (Thaumetopoea pityocampa-wilkinsoni complex), 
inferred by AFLP and mitochondrial DNA markers. Mol Ecol 11: $2435-2444$.

Salvato P, Simonato M, Patarnello T, Masutti L, Battisti A (2005). Do sexual pheromone traps provide biased information of the local gene pool in the pine processionary moth? Agric Forest Entomol 7: 127-132.

Sauvard D (1993). Reproductive capacity of Tomicus piniperda L. (Col., Scolytidae). 2. Analysis of the various sister broods. J Appl Entomol 116: 25-38.

Schneider S, Roessli D, Excoffier L (2000). Arlequin Version 2.001: A Software for Population Genetics Data Analysis.
Genetics and Biometry Laboratory, University of Geneva: Geneva.

Slatkin M (1987). Gene flow and the geographic structure of natural populations. Science 236: 787-792.

Van Dongen S, Matthysen E, Dhondt AA (1996). Restricted male winter moth (Operophtera brumata L.) dispersal among host trees. Acta Oecol 17: 319-329.

Weir BS, Cockerham CC (1984). Estimating F-statistics for the analysis of population structure. Evolution 38: 1358-1370.

Zhang DX (2004). Lepidopteran microsatellite DNA: redundant but promising. Trends Ecol Evol 19: 507-509. 